\title{
Notary Role in The Establishment of Foreign Investment Limited Company Based on The Act No. 25 Of 2007 on Investment in Semarang
}

\author{
Noor Rachmawati ${ }^{1}$ and Lathifah Hanim ${ }^{2}$
}

\begin{abstract}
Research on the role of the notary in the establishment of a Foreign Investment Limited Company (PMA) in Semarang aims to determine the role of a notary in the establishment PT.PMA. The research method is normative with library research and regulatory legislation in the field of investment include field research. This study uses a technique of direct communication with the tool in the form of interview guidelines. Interviews are used is free unstructured but questions that do not come out of the subject matter.

Based on the results of the study concluded that the role of the notary in the establishment of PT. PMA is based on Act No. 25 of 2007 on Investment in Semarang are procedures that should be implemented is the submission of PMA addressed to the Investment Coordinating Board (BKPM), with regard to this case, the task of the notary help the government provide legal counseling for the parties to the establishment, make Joint Venture Agreement in accordance with applicable legislation and in charge of manufacture of a limited liability company's certificate of incorporation approved by the Minister of Justice and Human Rights of the Republic of Indonesia. In the event of an error PT.PMA establishment, the notary is responsible for the deed change, but the responsibility of the notary in the case of the fraud perpetrated by the founder of the company who act in bad faith, then it becomes the responsibility of the founders of the company. Constraints faced by thebusiness licensing constraints, constraints business domicile, the determination of business areas, administrative requirements and constraints lack of capital to start build a company.

Keywords: Role of the Notary; Foreign Investment; Limited Company.
\end{abstract}

\section{Introduction}

Economic development, especially for the developing countries one of which is determined by the growth of foreign investment. Foreign investment flows are volatile and highly dependent on the investment climate of the country concerned. For investor before investing countries will first assess on aspects that affect the investment climate, namely: economic opportunity, rule of law, political stability. ${ }^{3}$

Indonesia itself is a developing country that needed a large capital or investment. ${ }^{4}$ Therefore, the issue of foreign investment have grown increasingly crowded discussed for national development basically requires a lot of funds. The funds needed for investment may not be fulfilled only from national governments and the private sector.

\footnotetext{
1 Student of Master of Notary Law, Faculty of Law UNISSULA, email noorrachmawati1983@gmail.com

${ }^{2}$ Lecturer of Faculty of Law Unissula Semarang

3Pancreas J Naggy, 2009, Country Risk, How to Asses, Quantify and Monitor, Euronomy Publications, London, p. 54

${ }^{4}$ Salim HS dan Budi Sutrisno, 2012, Hukum Investasi di Indonesia , PT Raja Grafindo Persada, Jakarta, p. 1
} 
The situation is further pushed so closely as pPTSPible to attract foreign investment in Indonesia. ${ }^{5}$

The main reason a country is to invite foreign capital to boost economic growth, in order to increase employment. Then, with the influx of foreign capital other goals to be achieved such as developing the industry to generate and save foreign exchange (import substitution, encouraging non-oil exports, transfer of technology, build infrastructure, develop underdeveloped regions). ${ }^{6}$

Investment law in Indonesia is regulated in Act No. 25 of 2007 on Investment. In Article 5 (2) of Act No. 25 of 2007 on Investment has been defined clearly about the legal form of foreign investment companies. Foreign investment shall be in the form of a limited liability company. In addition, the wording of Article 5, paragraph (2) of Act No. 25 of 2007 on Investment: "Foreign investment shall be in the form of a limited liability company under the laws of Indonesia and domiciled in the territory of the Republic of Indonesia, unless otherwise specified by the Law".

Limited Liability Company (PT) is a legal entity in which the existence of a new legal entity status acquired after obtaining approval from the competent authority, in this case a notary. As in Article 1 of Act No. 2 of 2014 concerning Notary stating that: "Notary is a public official authorized to make an authentic deed and have more authority as referred to in this Act or under the Act more". ${ }^{7}$

Notary has a duty to enter that what is contained in notarial truly understood and in accordance with the parties, that is the way to read it so that it became clear the contents of notarization, and provide access to information, including access to legislation relating to the the signatories deed. Therefore, the parties may determine to be free to approve the contents of the notarial deed to be signed.

Based on the above, the authors are interested in doing further research with the title: "Notary Role In The Establishment Of Foreign Investment Limited Company Based On The Act No. 25 of 2007 On Investment In Semarang". Therefore in this study the proposed formulation of the problem as follows: 1) How is the role of the notary in the establishment of a Limited Liability Company (PT) Foreign Investment under Act No. 25 of 2007 on Foreign Investment in Semarang?; 2) What are the obstacles encountered in the establishment of a Limited Liability Company (PT) Foreign Investment under Act No. 25 of 2007 on Foreign Investment in the city of Semarang and what's the solution?

\section{Research methods}

The method used in this paper is normative with the help of primary data or empirical data as supporting data. Normative legal research is the method of legal research conducted by examining of library materials, by analyzing through the Act as well as support from empirical data conducted to obtain primary data in order to get the truth in the office of the Investment Coordinating Board (BKPM) in Semarang.

\footnotetext{
${ }^{5}$ Panji Anoraga, 2008, Perusahaan Multinasional dan Penanaman Modal Asing , Dunia Pustaka Jaya, Jakarta, p. 46

${ }^{6}$ Erman Rajaguguk, 2008, Hukum Investasi di Indonesia, Fakultas Hukum Universitas Indonesia, Jakarta, p. 19

${ }^{7}$ Act No. 2 of 2014 concerning Notary.
} 


\section{Results And Discussion}

\subsection{The Role Of The Notary In The Establishment of A Limited Liability Company (PT) Foreign Investment under Act No. 25 of 2007 on Foreign Investment in Semarang}

The role of the notary in the establishment of PT PMA is intended to apply to the Agency Coordination of PMA (BKPM). In this regard, the task of helping the government notary provides legal counseling for the parties to the establishment of the Joint Venture Agreement made in accordance with applicable legislation and make the deed of establishment of PT. PMA. The responsibility of notaries in the establishment of PT. PMA when an error occurs notary is responsible for the deed change, but on the responsibility of the notary in the case of the fraud perpetrated by the founder of the company who act in bad faith, then it becomes the responsibility of the founders of the company.

Historically, the presence of Foreign Direct Investment (PMA) in Indonesia is actually not a new phenomenon, considering that foreign capital has been present in Indonesia since the colonial era. But of course the presence of foreign capital in the colonial period different from the period after independence, for the purpose of PMA in the colonial period dedicated to the interests of the colonizers and not for the welfare of the Indonesian people ${ }^{8}$.

According to Article 1 paragraph 3 of Act No. 25 of 2007 states: "Foreign investment is investing activity to do business in the territory of the Republic of Indonesia, made by a foreign investor, either using foreign capital or joint venture with a domestic investor".

Meanwhile, Article 1 item 8 of the Act No. 25 of 2007 states: "Foreign capital is capital owned by foreign countries, foreign individuals and / or legal entities Indonesia are partly or wholly owned by foreign parties".

Pursuant to Article 5 paragraph (2) of Act No. 25 of 2007 states, "Foreign investment shall be in the form of a limited liability company under the laws of Indonesia and domiciled in the territory of the Republic of Indonesia, unless another ditentukaan by Act".

The main problem faced by investors in starting a business in Indonesia observed by this Act so that there is the endorsement and licensing arrangement in which there are regulations concerning the one stop service. With this system, it is expected that the integrated services at the center and in the area can create licensing simplification and acceleration of the settlement. In addition to the system service area, the Regional Investment Coordinating Board (BKPMD) was given the task of coordinating the implementation of the investment policy. ${ }^{9}$

${ }^{8}$ David Kairupan, 2013, Aspek Hukum Penanaman Modal Asing di Indonesia, Kencana Prenada Media Grup, First Edition, p. 1

${ }^{9}$ Sujud Margono, 2009, Hukum Investasi Asing di Indonesia , Novindo Pustaka Mandiri, p. 22 
Notaries have the authority in the endorsement of the product Incorporation and Business Registration, among others: ${ }^{10}$

- Registration of Investment

It is compulsory for foreign capital investment (PMA) and carried through One Stop Services (PTSP) Investment in the BKPM to get Admission Permit. Used as a means of checking whether the business field that will be entered not included in the Negative List Investment.

Investment by the PMA Registration can be done before or after its Notary Act and Ratification of Corporate Law Firm of the Ministry of Justice and Human Rights. But after getting Investment License Registration, must be followed up with the creation of the company and Validation certificate Corporate Entity.

- Taxpayer Identification Number (TIN)

Are required for individuals and business entities including foreign capital investment (PMA) and domestic investment and a requirement for the manufacturing certificate of business entities and business entities to perform economic activities / business region of Indonesian law. Being identity imposed tax obligations of economic activities. TIN filed and processed at the tax office in each county.

- Deed Enterprises

It is compulsory for foreign capital investment (PMA) to obtain the status of a limited liability corporation (PT) which is valid for those who have to register investment or to do registration of investment. It is compulsory for the Domestic Investment (DCI) to obtain the status of a business entity (PT, CV, FA, individuals, cooperative, foundation) which approved in principle a legitimate before investment and other licensing in the context of business operations. Enterprise certificate issued by a notary and must obtain authorization from the Ministry of Justice and Human Rights.

- Endorsement Business Law Firm

Deed to be done with business entities that have been made so that legitimate business entity as a legal entity Limited Liability Company. Law Firm legal status a requirement for investment and to continue the process of obtaining a license investments and operations at a later stage.

BKPM really need to legalize or certify the notary deed of incorporation of a Limited Liability Company (PT). When it is completed, the potential investors are able to apply for a Taxpayer Identification Number (TIN), in-principle license, and permit the establishment of PT in the same time, as noted in Economic Policy Package Volume II. ${ }^{11}$

\footnotetext{
${ }^{10}$ http://nswi.bkpm.go.id/wps/portal/!ut/p/c4/04_SB8K8xLLM9MSSzPy8xBz9CP0os3hDAwNPJyd DRwMLXx9jA0zwBADE5MwI3d_M_2CbEdFAIjkPT4!/?PC_7_100IBB1A08ML30I6QT044V24E3000 000_WCM_CONTEXT=/wps/wcm/connect/nswi/nswi/panduan+investasi/pendirian+usaha, accessed at March 30, 2016, at $14.15 \mathrm{pm}$

11 http://www.cnnindonesia.com/ekonomi/20151001144409-92-82134/bkpm-sulitcari-notarisuntuk-wujudkan-perizinan-usaha-3-jam/, accessed on March 30, 2016, at 14:46 pm
} 
Each of the process of establishing a Limited Liability Company (PT) should be according to the provisions and procedures referred to Law of PT No. 40 Of 2007 regarding Limited Liability Company. Steps that need to be passed, among others:

- Filing Limited Company Name

Filing the company name was registered by a notary through Legal Entity Administration System (Sisminbakum) Kemenkumham. The requirements are needed as follows:

- Attach the original power of attorney forms and establishment;

- Attach a photocopy of Resident Identity Card (KTP) founders and management;

- Attach a photocopy of family card (KK) leader / founder of PT.

Registration PT aims to obtain approval from the relevant authorities (Kemenkumham) in accordance with the Company Law and the Indonesian Government Regulation No. 43 Of 2011 on Procedures and Use of Name Limited company.

- Preparation of Deed of Establishment

Making the notary deed of incorporation carried out by the authorities throughout the territory of the Republic of Indonesia to further obtain the Agreement of the Minister Kemenkumham. Ought to be understood, there are things that need to be considered in making this deed, ie, Position PT, where PT should be in the territory of the Republic of Indonesia to name the town where the PT conducting business as the Central Office.

- SKDP Manufacture

Request SKDP (Domicile Company) was submitted to the local district office according to the office address of the applicant is located, which, as evidence of information / existence of the company address (domicile of the building, if the building). Other requirements needed are: photocopy of Land and Building Tax (PBB) last year, Rental Agreements or contracts business premises for those who live not in an office building, Identity Card (KTP) Director, Permit to Build (IMB) if PT is not in office building.

- TIN Manufacture

TIN registration application submitted to the Head of the Tax Office in accordance with the existence of domicile PT. Other requirements are needed, are: personal TIN Director of PT, photocopy of ID card of the Director (or photocopy of passport for foreigners, special PMA), SKDP, and the deed of establishment of PT.

- Preparation of the Articles of Association

These claims are submitted to the Minister for approval Kemenkumham Articles of Association (certificate of incorporation) as a legal entity PT in accordance with the Company Law. Requirements needed include:

- Proof of bank deposit worth of paid-up capital in the deed of

- Proof of Non Tax Revenue (non-tax) as payment of state event news

- The original certificate of incorporation.

- Asking License 
This License allows the PT to operation. However, it is necessary to note that every company should make the License, during the exercise of business activities included in the Standard Industrial Classification of Indonesia (KBLUI) as Head of Statistics Regulation No. 57 Of 2009 on the Indonesian Standard Industrial Classification.

- Asking Company Registration (TDP)

Applications for registration submitted to the Head of the Department of Trade and Industry and / or Cooperative Micro Small Medium Enterprises and Trade-related city or county in accordance with the company's domicile. For companies that have registered will be given a certificate TDP as evidence that the company / entity has conducted company registration in accordance with Regulation of the Minister of Trade of the Republic of Indonesia 37 / M-DAG / PER / 9/2007 on the Implementation of Company Registration.

- Minutes of the Republic of Indonesia (BNRI)

After the company and the company registration has been approved by the Minister Kemenkumham, it must be announced in BNRI of the company that was published in the BNRI, the PT has a perfect status as a legal entity.

\subsection{Obstacles encountered in the establishment of a Limited Liability Company (PT) Foreign Investment under Act No. 25 of 2007 on Foreign Investment in the city of Semarang and solutions.}

Obstacles encountered include: $:^{12}$

- Constraints Business Licensing

Not a few businesses that still do not understand well the type of business licenses needed for his business. One influential factor is the wide variety of business license in Indonesia and each has its stages and requirements that may be different from each other. In the Licensing menu in the field of trade alone, there are about 62 types of business licenses. Not to permit navigation in other fields.

This ignorance can make you even obtain a business license that is not needed or even the wrong business license altogether. If this is the case is certainly not efficient in time and cost. Because of this ignorance also, in some cases, there are businesses that wrong strategies in doing business legally.

For example, you want to set up a travel agency company (travel) and clothing trade. Then you set up PT (Limited company) and enter these two business fields in the deed of your PT. But apparently when taking care of business permits, you just know that both these business areas using a different license. Travel agents require a business license named TDUP (Business Registry of Tourism), while trade in the form of clothing requiring business license License (Trade Permit).

To overcome this first obstacle, it helps to first understand the business to be established. If business is to be established is something new, it is necessary to recognize the character of the business in order to identify the type of license required. For example, if you want to do business through media advertising LCD

12 https://easybiz.id 
screen attached to the vehicle body such as cars and trucks. Here can take care of License as a business license because the basic of this business is advertising services.

- Constraints Business Domicile

A business entity shall have a business domicile. Moreover, in some areas can no longer use the residence as a domicile. If the entity that will be established in the form of PT (Limited company), this obligation confirmed in Article 5 of Act No. 40 of 2007 on Limited Liability Company (Law 40/2007). Legal business domicile in representative locations can create a positive perception for prospective clients and potential partners of the company. And most importantly, their business domicile for business entities required to take care of the legality of documents required by the company. Indeed business domicile address will appear in every document the legality of the company, ranging from SKDP to TDP. Both of these reasons can at least be motivated to wisely choose the right business domicile for business.

In addition, in choosing a business domicile should use buildings that designation is for the business. This designation type can be seen in the document IMB (Building Permit) from the building. Indeed, in some areas are still allowed to use the residence as a business domicile, but chose a building with the designation IMB place of business would be anticipatory measures for the sustainability of the company.

For example, in the area of Semarang previously could use the house as a place of business. But now despite using house, designation listed in his IMB must for the business. So rather than at any time local government to change its policies that led to the necessity you are looking for other business domicile, anticipatory steps above could be an option.

- Determining the Business Sector

This constraint is closely related to the first obstacle that is a matter of business licensing. Hence, the need to determine the exact line of business so that no one in identifying the required business license. When already know what line of business you want to run, there are two (2) things that must be considered.

First, related to the KBLI (Standard Industrial Classification of Indonesia. KBLI fully regulated in the Regulation of Head of Statistics Number 95 Of 2015 concerning Indonesian Standard Industrial Classification. In KBLI, we can see a variety of business sectors in Indonesia. These business areas are listed in the form of codes of business areas along with an explanation of coverage per code. Not all KBLI code can be included in the License (Trade Permit). But by knowing the business to be run entry code which business field, it will know whether enough has actually had to take care License or other business license type. If you find that line of business to be run is not in the KBLI, it can refer to the code with a description similar business field or close to the description field of business will be run.

Second, Related DNI (Negative List Investment), if you plan to set up a company with the involvement of foreign capital, it is not enough attention to KBLI, but also must pay attention to the DNI (Negative List Investment). Foreign capital is capital 
that comes from the foreigners (foreign citizens) and / or a foreign company (the company founded not by the laws of Indonesia). When companies involving foreign capital, means must be established PT PMA (Foreign Investment). DNI fully present in the Presidential Decree Number 44 Of 2016 concerning List of Closed Business Field and Field Open with Requirement in the Field of Investment (Presidential Decree 44/2016).

- Constraints Administrative Requirements

These constraints include various administrative requirements in each phase of the legality of the document processing company. For example, for the maintenance phase SKDP (Domicile Company) which need to take care of first BPJS Employment on behalf of the company. This is because the certificate BPJS Employment is one of the required documents while taking care of SKDP. Besides BPJS Employment, also need to attach the Family Card of the Director of the company.

SKDP addition, another problem is when taking care of a TIN (Taxpayer Identification Number) on behalf of the Agency. When taking care TIN This body, need to ensure that the TIN's private Managing Director of the company you already have the latest format where the card TIN the person listed NIK (Population Identification Number) and the same address with the NIK and address listed in KTP (Identity Card ) of the Director of the company. So if you want to establish PT or set up a CV, while the TIN is not in accordance with the latest formats, it is better to come to the local tax office to renew TIN.

- Capital Constraints For Companies Found

The majority still think that founded the company in particular PT needs a lot of capital and costs. In Act 40/2007 indeed there is a provision that authorized capital of at least Rp. 50 million and $25 \%$ of the authorized capital shall be paid in full.

Aware that the rules of the authorized capital and paid-up capital can be burdensome entrepreneurs, the Government recently issued Government Regulation No. 29 of 2016 on the Amendment Authorized Capital Limited company (PP 29/2016). In Article 1 (3) PP 29/2016 is mentioned that the amount of authorized capital of PT can be determined by mutual agreement of the founders of PT. That is, can deviate the capital rules in Law 40/2007. Because of this simplicity, PP 29/2016 also specifies that within 60 days since the deed was signed, proof of deposit must be submitted to the Minister of Justice and Human Rights. So the ability to determine the appropriate capital.

\section{Closing}

\subsection{Conclusion}

Based on the discussion above it can be concluded:

- The role of the notary in the establishment of a Limited Liability Company (PT) Foreign Investment under Act No. 25 of 2007 on Foreign Investment in the city of Semarang, namely:

- PMA Filing an application addressed to the Board Koordinasi (BKPM), with regard to this case, the task of helping the government notary provides legal counseling for the parties to the establishment of the Joint Venture Agreement made in 
accordance with applicable legislation and make the deed of establishment of PT. PMA.

- The responsibility of notaries in the event of an error PT.PMA establishment notary deed is responsible for the change, but on the responsibility of the notary in the case of the fraud perpetrated by the founder of the company who act in bad faith, then it becomes the responsibility of the founders of the company.

- Obstacles encountered in the establishment of a Limited Liability Company (PT) Foreign Investment under Act No. 25 of 2007 on Foreign Investment in the city of Semarang, namely:

- Constraints Business Licensing

- constraints Business Domicile

- Determining the Business Sector

- Constraints Administrative Requirements

- Capital Constraints For Companies Found

The solution is:

- Understanding the business must first be established. If business is to be established is something new, it is necessary to recognize the character of the business in order to identify the type of license required.

- Legal business domicile in representative locations can create a positive perception for prospective clients and potential partners of the company. This reason can at least be motivated to wisely choose the right business domicile for business. in choosing a business domicile should use buildings that designation is for the business.

- Need to determine the exact line of business so that no one in identifying the required business license. When already know what line of business you want to run, there are two (2) things that must be considered. First, with regard to KBLI (Standard Industrial Classification of Indonesia; Second, related to the DNI (Negative List Investment).

- Administration must be adapted to the latest format by visiting the office directly to local administrative proceedings.

- Determine capital according to ability, it is based on Government Regulation No. 29 of 2016 on the Amendment Authorized Capital Limited company (PP 29/2016).

\subsection{Suggestion}

- Notaries are expected to have the ability and knowledge in the field of foreign investment, so that potential investors are more confident to invest in Indonesia.

- It is expected for the government to trim and simplify licensing, so that potential investors are interested to invest in Indonesia.

\section{References}

[1] Anoraga, Panji, 2008, Perusahaan Multinasional dan Penanaman Modal Asing , 
Dunia Pustaka Jaya, Jakarta

[2] Kairupan, David, 2013, Aspek Hukum Penanaman Modal Asing di Indonesia, Kencana Prenada Media Grup, Edisi Pertama

[3] Margono, Sujud, 2007, Hukum Investasi Asing di Indonesia , Novindo Pustaka Mandiri

[4] Naggy, Pancreas J, 2009, Country Risk, How to Asses, Quantify and Monitor, Euronomy Publications, London

[5] Rajaguguk, Erman, 2008, Hukum Investasi di Indonesia, Fakultas Hukum Universitas Indonesia, Jakarta

[6] Salim, HS dan Sutrisno, Budi, 2012, Hukum Investasi di Indonesia, PT Raja Grafindo Persada, Jakarta

[7] Constitution of the Republic of Indonesia in 1945.

[8] The Book of Commercial Law.

[9] Code of Civil law.

[10] Act No. 2 of 2014 concerning Notary.

[11] Act No. 40 of 2014 regarding Limited Liability Company.

[12] http://nswi.bkpm.go.id/wps/portal/!ut/p/c4/04_SB8K8xLLM9MSSzPy8xBz9CP0o3 hDAwNPJydDRwMLXx9jA0zwBADE5MwI3d_M_2CbEdFAIjkPT4!/?PC_7_100IBB1A 08ML30I6QT044V24E3000000_WCM_CONTEXT=/wps/wcm/connect/nswi/nswi/p anduan+investasi/pendirian+usaha, accessed at March 30, 2016

[13] http://www.cnnindonesia.com/ekonomi/20151001144409-92-2134/bkpmsulitcari-notaris-untuk-wujudkan-perizinan-usaha-3-jam/, accessed on March 30, 2016

[14] http://easybiz.id 